\title{
FRMAC ASSESSMENT MANUAL
}

\section{Addendum}
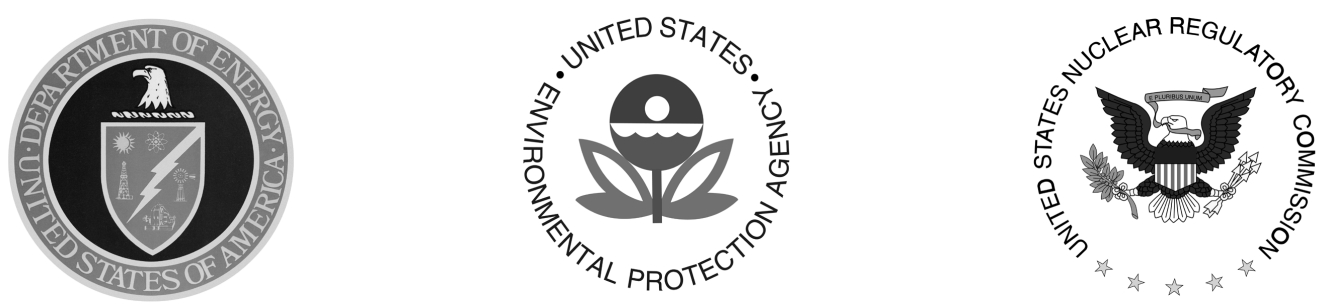

The Federal Manual

for Assessing Environmental Data During a Radiological Emergency

DECEMBER 1999 
Available for sale to the public, in paper, from:

U.S. Department of Commerce

National Technical Information Service

5285 Port Royal Road

Springfield, VA 22161

phone: 800.553 .6847 or 703.605 .6000

fax: 703.605.6900

email: orders@ntis.fedworld.gov

online ordering: http://www.ntis.gov/ordering.htm

Available for a processing fee to U.S. Department of Energy and its contractors, in paper, from:

U.S. Department of Energy

Office of Scientific and Technical Information

P.O. Box 62

Oak Ridge, TN 37831-0062

phone: 865.576 .8401

fax: 865.576.5728

email: reports@adonis.osti.gov

Available electronically at http://www.doe.gov/bridge 


\section{ADDENDUM \\ FRMAC ASSESSMENT MANUAL}

\section{Ingestion Assessment-Intermediate Phase Adoption of 1998 FDA Protective Action Guidelines (PAGs)}

\subsection{PURPOSE}

The ingestion pathway assessment procedures cited in the current version of the FRMAC Assessment Manual, DOE/NV/11718-061 (September 1996) have been superseded by new U.S. Food and Drug Administration (FDA) guidance. This addendum replaces the obsolete procedures with a revised set based on the new guidance released by the FDA in August 1998.

This addendum provides an overview of the new guidance, revised assessment methods, and assessment aids. It does not provide a general method of ingestion pathway analysis. The scope is limited to that covered by the new guidance titled, "Accidental Radioactive Contamination of Human Food and Animal Feeds: Recommendations for State and Local Agencies," issued by the FDA in August 1998.

\subsection{APPLICABILITY}

This addendum rescinds immediately Procedures M.5.0 through M.5.10 with their associated tables, charts, and worksheets as found in Section 5 (Ingestion Assessment-Intermediate Phase) of both Volumes 1 and 2 of the FRMAC Assessment Manual. Procedures M.5.11 through M.5.14 remain in force (dose computation). The procedures cited in this addendum immediately become the default procedures for ingestion assessment, replacing the rescinded procedures specified above. This addendum will remain in force until explicitly rescinded or superseded by issue of a revised FRMAC Assessment Manual.

These procedures address the accidental radioactive contamination of human food during the intermediate phase. That is, this guidance is designed only for the first year following an accidental contamination. Applicability after that is subject to modification based on circumstances and technical details. The procedures are applicable to water to the extent it is part of human food. However, water, in general, is still governed by the Clean Water Act. The deliberate and regulated introduction of radioactivity into human food and animal feed is not addressed by these procedures.

As always, FRMAC will accommodate state-specific procedures that may differ from those described in the following sections. These procedures may be modified if the deviation with justification is documented and approved by the FRMAC Director. 


\subsection{OVERVIEW OF NEW FDA PAGS}

The FDA issued guidance for the protection of the ingestion pathway from accidental contamination of food in October 1982. This has been the basis for protective actions until recently. Since then there have been significant advancements related to emergency planning to warrant updating the recommendations. Therefore, the FDA issued new guidance in August 1998 and rescinded the previous guidance. The new guidance builds on the new technical information, the experience gained since the Chernobyl accident, and the guidance developed by the international community. The full text of the new 1998 FDA guidance can be found on the Internet at:

http://www.fda.gov/cdrh/dmqrp/84.html [accessed on December 10, 1999].

The new guidance established revised PAGs that restrict the CEDE (Committed Effective Dose Equivalent) to $5 \mathrm{mSv}$. (0.5 rem) or the CDE (Committed Dose Equivalent) to any specific organ to $50 \mathrm{mSv}$. (5 rem), whichever is most limiting. The PAGs are then expressed in term of measurable quantities called DILs (Derived Intervention Levels). These DILs are limits on the concentration of radioactive contamination in food. A DIL corresponds to the concentration of radioactivity in food, which could lead to an individual in the most sensitive population receiving a dose equal to the PAG if no intervention were taken for the year.

The DILs were computed with respect to the most sensitive population for five types of nuclear accidents (reactor, fuel-reprocessing, waste, weapons, and spacecraft). Analysis of these scenarios leads to the identification of nine radionuclides that essentially control dose. These nine radionuclides are divided into five groups having similar characteristics: ${ }^{90} \mathrm{Sr},{ }^{131} \mathrm{I},{ }^{134} \mathrm{Cs}+{ }^{137} \mathrm{Cs}$, ${ }^{103} \mathrm{Ru}+{ }^{106} \mathrm{Ru}$, and ${ }^{238} \mathrm{Pu}+{ }^{239} \mathrm{Pu}+{ }^{241} \mathrm{Am}$. The DILs for these five groups are those that are principally utilized for assessment (also called principal radionuclides in FDA guidance).

The DIL is defined as

$$
\operatorname{DIL}(\mathrm{Bq} / \mathrm{kg})=\frac{\mathrm{PAG}(\mathrm{mSv})}{\mathrm{DC}(\mathrm{mSv} / \mathrm{Bq}) \times \text { Food Intake }(\mathrm{kg}) \times \mathrm{f}}
$$

The dose coefficient (DC) is specific for each nuclide. The Food Intake is for each age group that is evaluated ( $3 \mathrm{mo}, 1 \mathrm{yr}, 5 \mathrm{yr}, 10 \mathrm{yr}, 15 \mathrm{yr}$, and adult $[>17 \mathrm{yr}]$ ) and $\mathrm{f}$ (fraction of total diet contaminated) is 30 percent (assumes $<10$ percent of total diet from contaminated area, $3 \times$ accounts for special subpopulations). It is important to note that Food Intake is for the entire diet, not for any one type of food. Therefore, the DILs apply to every component of the entire diet, which includes drinking water. The DILs are applicable to foods as prepared for consumption. Assessment of dehydrated food should consider reconstitution. Both raw foods and prepared foods are assessed asis. Dilution of contamination by mixing with uncontaminated food to avoid assessment as contaminated is illegal under the regulations of the Food, Drug, and Cosmetic Act. However, concentrations in spices should be compared to 10 times the DIL, because of the very small quantity consumed. 
The DILs for the five principal nuclide groups are cited in Table 1. Details of computation and supporting data are cited in the full text of the 1998 FDA guidance. These DILs may be applied to foods for human consumption immediately following an accident. However, the DILs should be evaluated as soon as possible to assure they are appropriate for the incident. That is, there

Table 1. DILs for the Five Principal Nuclide Groups

\begin{tabular}{l|c|c}
\hline Radionuclide Group & Bq/kg & pCi/kg \\
\hline${ }^{90} \mathrm{Sr}$ & 160 & 4,300 \\
${ }^{131} \mathrm{I}$ & 170 & 4,600 \\
${ }^{134} \mathrm{Cs}+{ }^{137} \mathrm{Cs}$ & 1,200 & 32,000 \\
${ }^{238} \mathrm{Pu}+{ }^{239} \mathrm{Pu}+{ }^{241} \mathrm{Am}$ & 2 & 54 \\
${ }^{103} \mathrm{Ru}+{ }^{106} \mathrm{Ru}$ & $\mathrm{C}^{103} \mathrm{Ru} / 6,800+\mathrm{C}^{106} \mathrm{Ru} / 450<1$ & $\mathrm{C}^{103} \mathrm{Ru} / 180,000+\mathrm{C}^{106} \mathrm{Ru} / 12,000<1$ \\
\hline
\end{tabular}

may exist circumstances where contributions by radionuclides other than those in the five groups previously cited may be controlling. Therefore, 15 additional DILs are provided in Appendix E of the new guidance for those radionuclides next most likely to be of significance.

NOTE: The five principal DILs are applied separately, not summed as in the previous guidance. Similarly, the 15 additional DILs are applied separately. If any one DIL is exceeded, then the food is determined to exceed the PAG.

\subsection{ASSESSMENT METHODS}

\subsection{Outline}

The basic process for ingestion assessment is time-phased and proceeds in five steps:

a. Assess model predictions and early exposure-rate data to suggest where PAGs may be exceeded. This assessment will be useful in the first day following the accident to convey the potential magnitude of the incident. Employ Procedure 4.2, "Rules-of-Thumb."

b. Assess soil samples and field gamma spectroscopy to refine estimate of where PAGs may be exceeded. This assessment will be useful for the first few days when few, if any, food sample analyses are available. Employ Procedure 4.3, "Deposition Contamination Analysis."

c. Assess food samples in broad classes (human food, milk, forage). This approach will suffice for the first week or so until enough data are available to visualize a more detailed picture, which addresses specific foods. Employ Procedure 4.4, "Food Contamination Analysis." 
d. Evaluate minor radionuclides and determine controlling radionuclides. This evaluation should be done by the seventh day. Employ Procedure 4.5, "Minor Radionuclide Analysis."

e. Assess individual lots of food. This is a later-term consideration to support controls that have been implemented. Employ Procedure 4.4, "Food Contamination Analysis," modified to include dominant radionuclides, if necessary.

These procedures may be modified if the deviation with justification is documented and approved by the FRMAC Director.

\subsection{Rules-of-Thumb}

Compare model predictions or early measurements to these special rules-of-thumb. These values, model predictions, and preliminary measurements are crude estimates and should be superseded by better data as soon as available (day 2).

Table 2. Rules-of-Thumb

\begin{tabular}{l|l|l|l}
\hline Accident Scenario & $\begin{array}{l}\text { Exposure Rate } \\
(\mathbf{R} / \mathbf{h})\end{array}$ & Deposition & Limitations \\
\hline $\begin{array}{l}\text { Reactor, fuel reprocessing, } \\
\text { and waste }\end{array}$ & $\begin{array}{l}0.5 \mu \mathrm{R} / \mathrm{h}^{+} \\
(12 \mathrm{hr} \text { after } \\
\text { shutdown) }\end{array}$ & $\begin{array}{l}50 \mathrm{nCi} / \mathrm{m}^{2} \beta \\
\sim 1,000 \mathrm{dpm} \beta \\
(12 \mathrm{hr} \text { after shutdown })\end{array}$ & $\begin{array}{l}\text { time dependent } \\
\text { (see figures 1 \& 2) }\end{array}$ \\
\hline $\begin{array}{l}\text { Nuclear weapon and } \\
\text { RTG/RHU (spacecraft) }\end{array}$ & not applicable & $\begin{array}{l}0.5 \mathrm{nCi} / \mathrm{m}^{2} \alpha \\
(12 \mathrm{dpm}) \alpha\end{array}$ & \\
\hline
\end{tabular}

Assumes $2 \mathrm{~kg} / \mathrm{m}^{2}$ productivity and retention of 1.0 for iodine and 0.2 for all other radionuclides.

Mix taken from Table 4.3 of September 1996 FRMAC Assessment Manual.

† Minimum detectable man-made contribution detectable by Aerial Measuring System helicopter

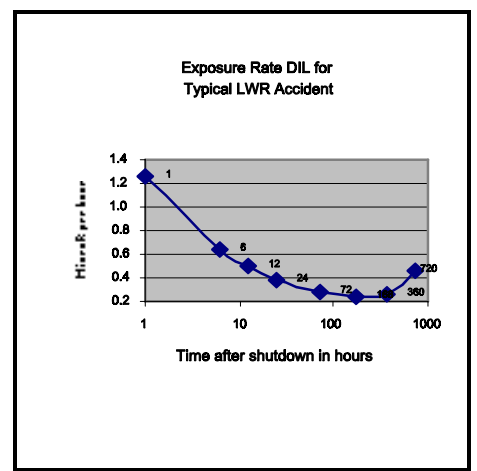

Figure 1. Exposure Rate DIL

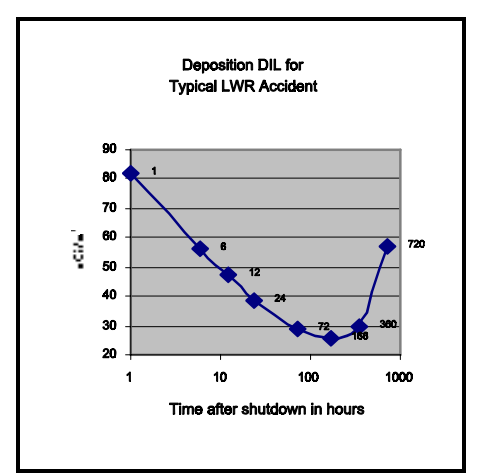

Figure 2. Deposition DIL 


\subsection{Deposition Concentration Ingestion Analysis}

Early when few, if any, food analyses are available, soil samples and field gamma spectroscopy can be utilized to better define the zone likely to exceed the ingestion PAGs. Because the FDA guidance is based on food sample analyses, this is only a preliminary assessment until a sufficient number of food sample analyses are available to rely on them alone.

Use Worksheet A, "Deposition Concentration Ingestion Analysis," to evaluate deposition of the five groups of radionuclides of primary interest. The worksheet contains deposition DILs that were computed from the FDA DILs assuming $2 \mathrm{~kg} / \mathrm{m}^{2}$ productivity and a retention factor of 1.0 for iodine and 0.2 for all other radionuclides. The worksheet is comprised of four tests. If any one test fails, then the food from the area may exceed the FDA guidelines. This procedure does not address minor radionuclides.

Instructions For Worksheet A, "Deposition Concentration Ingestion Analysis"

${ }^{90} \mathrm{Sr}$ and ${ }^{131}$ I Tests

1. Enter the deposition concentration for ${ }^{90} \mathrm{Sr}$ and ${ }^{131} \mathrm{I}$, in Column A.

2. Note units of deposition measurement; select DIL with matching units from Column B.

3. Determine ratios for both nuclides by dividing concentration (A) by proper DIL (B); enter in Column C.

4. If the ratio for either ${ }^{90} \mathrm{Sr}$ or ${ }^{131} \mathrm{I}$ (C) exceeds 1.0, mark such in Column D with an X.

${ }^{134} \mathrm{Cs}+{ }^{137}$ Cs Test

1. Enter the deposition concentration for ${ }^{134} \mathrm{Cs}$ and ${ }^{137} \mathrm{Cs}$, in Column A.

2. Sum the concentrations and enter at the bottom of Column A as "Sum $\sum A$."

3. Note units of deposition measurement; select DIL with matching units from Column B.

4. Determine ratio by dividing "Sum $\sum A$ " (A bottom row) by proper DIL (B); enter ratio in Column C.

5. If the ratio $(\mathrm{C})$ exceeds 1.0 , mark Column $\mathrm{D}$ with an $\mathrm{X}$.

${ }^{238} \mathrm{Pu}+{ }^{239} \mathrm{Pu}+{ }^{241} \mathrm{Am}$ Test

1. Enter the deposition concentrations for ${ }^{238} \mathrm{Pu},{ }^{239} \mathrm{Pu},{ }^{241} \mathrm{Am}$, in Column A.

2. Sum the concentrations and enter at the bottom of Column A as "Sum $\sum$ A."

3. Note units of deposition measurement; select DIL with matching units from Column B.

4. Determine ratio by dividing "Sum $\sum A$ " (A bottom row) by proper DIL (B); enter ratio in Column C.

5. If the ratio (C) exceeds 1.0 , mark Column $\mathrm{D}$ with an $\mathrm{X}$. 
${ }^{103} \mathrm{Ru}+{ }^{106} \mathrm{Ru}$ Test

1. Enter the deposition concentrations for ${ }^{103} \mathrm{Ru}$ and ${ }^{106} \mathrm{Ru}$, in Column A.

2. Note units of deposition measurement; select DIL with matching units from Column B for both radionuclides.

3. Determine ratio for each by dividing concentration (A) by proper DIL (B); enter in Column C.

4. Sum the ratios at the bottom of Column $\mathrm{C}$ as "Sum $\sum \mathrm{A} . "$

5. If either the ratio or the ratio sum (C) exceeds 1.0, mark Column D with an X.

Finally, review Column D. If marked with an X for any test (meaning the ratio in Column C exceeds 1.0), then the sample exceeds PAG. Mark the box This Sample Exceeds PAG. If no test is flagged with an $\mathrm{X}$ in Column D (meaning all tests ratios are less than 1.0), then the sample is acceptable. Mark the box This Sample is OK.

\subsection{Food Contamination Analysis}

This is the principal means of assessment for ingestion concerns. Use Worksheet B, "Food Contamination Analysis," to assess human foods. The procedure is nearly identical to the procedure for deposition analysis but makes no assumptions about deposition details. Only the five groups of radionuclides of primary interest are addressed. This section does not address minor radionuclides, which are discussed in Section 4.5. The worksheet is comprised of four tests. If any one test fails, then that food exceeds the FDA guidelines.

Remember to apply the following application guidelines: (a) tests valid for food as prepared for consumption, (b) raw foods get no credit for potential contamination reduction measures, (c) spices should be compared to 10 times the DIL.

Instructions For Worksheet B, "Food Contamination Analysis"

${ }^{90}$ Sr and ${ }^{131}$ I Tests

1. Enter the food concentration for ${ }^{90} \mathrm{Sr}$ and ${ }^{131} \mathrm{I}$, in Column A.

2. Note units of concentration measurement; select DIL with matching units from Column B.

3. Determine ratios for both nuclides by dividing concentration (A) by proper DIL (B); enter in Column C.

4. If the ratio for either ${ }^{90} \mathrm{Sr}$ or ${ }^{131} \mathrm{I}$ (C) exceeds 1.0 , mark such in Column D with an X.

${ }^{134} \mathrm{Cs}+{ }^{137}$ Cs Test

1. Enter the food concentration for ${ }^{134} \mathrm{Cs}$ and ${ }^{137} \mathrm{Cs}$, in Column A.

2. Sum the concentrations and enter at the bottom of Column A as "Sum $\sum$ A."

3. Note units of concentration measurement; select DIL with matching units from Column B. 
4. Determine ratio by dividing "Sum $\sum A$ " (A bottom row) by proper DIL (B); enter ratio in Column C.

5. If the ratio (C) exceeds 1.0, mark Column D with an $\mathrm{X}$.

${ }^{238} \mathrm{Pu}+{ }^{239} \mathrm{Pu}+{ }^{241} \mathrm{Am}$ Test

1. Enter the food concentrations for ${ }^{238} \mathrm{Pu},{ }^{239} \mathrm{Pu},{ }^{241} \mathrm{Am}$, respectively, in Column A.

2. Sum the concentrations and enter at the bottom of Column A as "Sum $\Sigma A$ ".

3. Note units of concentration measurement, select DIL with matching units from Column B.

4. Determine ratio by dividing "Sum $\sum \mathrm{A}$ " (A bottom row) by proper DIL (B); enter ratio in Column C.

5. If the ratio $(\mathrm{C})$ exceeds 1.0 , mark Column $\mathrm{D}$ with an $\mathrm{X}$.

${ }^{103} \mathrm{Ru}+{ }^{106} \mathrm{Ru}$ Test

1. Enter the food concentrations for ${ }^{103} \mathrm{Ru}$ and ${ }^{106} \mathrm{Ru}$, in Column $\mathrm{A}$.

2. Note units of concentration measurement; select DIL with matching units from Column B for both radionuclides.

3. Determine ratio for each by dividing concentration (A) by proper DIL (B); enter in Column C.

4. Sum the ratios at the bottom of Column $\mathrm{C}$ as "Sum $\sum \mathrm{A}$. ."

5. If either the ratio or the ratio sum (C) exceeds 1.0, mark Column D with an X.

Finally, review Column D. If marked with an $\mathbf{X}$ for any test (meaning the ratio in Column C exceeds 1.0), then the sample exceeds PAG. Mark the box This Sample Exceeds PAG. If no test is flagged with an $\mathbf{X}$ in Column D (meaning all tests ratios are less than 1.0), then the sample is acceptable. Mark the box This Sample is OK.

\subsection{Minor Radionuclide Analysis}

This procedure assesses the contribution of the minor radionuclides and identifies the radionuclides that control the assessment outcome for human foods. The FDA methodology identified nine radionuclides as those most likely to dominate assessment results $\left({ }^{90} \mathrm{Sr},{ }^{131} \mathrm{I},{ }^{134} \mathrm{Cs},{ }^{137} \mathrm{Cs},{ }^{103} \mathrm{Ru},{ }^{106} \mathrm{Ru},{ }^{238} \mathrm{Pu}\right.$, $239 \mathrm{Pu}$, and ${ }^{241} \mathrm{Am}$ ). For the nuclear reactor, nuclear weapons, and radioisotope thermoelectric generator/radioisotope heater unit (RTG/RHU) spacecraft accident scenarios, these will generally suffice. However, there exist circumstances, particularly involving fuel reprocessing, waste and certain reactor accidents, where contributions by radionuclides other than those nine will be important or controlling. Therefore, 15 additional DILs are provided in the FDA PAGs for those radionuclides next most likely to be of significance. The following procedure evaluates those radionuclides and establishes the dominant radionuclides.

Use Worksheet C, "Minor Radionuclide Analysis," to assess the significance of the 15 remaining nuclides and identify the dominant species. Step 1 assesses the 15 minor radionuclides by ratio of food concentration to the respective DIL. If any one test fails (ratio $>1.0$ ), then that food exceeds the FDA 
guidelines. Step 2 defines the group of dominant radionuclides. It first rank orders the ratios of the minor radionuclides with those obtained from Worksheet B for the nine principal radionuclides. All radionuclides, with a ratio greater than $1 / 5$ of the most dominant radionuclide, are defined as dominant radionuclides. If it is determined that the minor radionuclides need to be included in the food analysis, then Step 1 of Worksheet C will serve as the supplement to Worksheet B to complete the "Food Contamination Analysis."

If any minor radionuclides are among the set of dominant radionuclides, then they must be included in future assessments of foods. If a consistent set of radionuclides can be demonstrated as dominant, then assessment need only be performed for those radionuclides. Be aware that the list of dominant radionuclides may change with time, because of decay. 
Instructions for Worksheet C, "Minor Radionuclide Analysis"

Minor Radionuclides

Step 1 Assess Minor Radionuclides

1. Enter the food concentrations for each radionuclide in Column A.

2. Note units of concentration measurement; select DIL with matching units from Column B.

3. Determine ratios for both nuclides by dividing concentration (A) by proper DIL (B); enter ratio in Column C.

4. If the ratio in any row of Column $\mathrm{C}$ exceeds 1.0, then the sample exceeds PAG. Mark the box This Sample Exceeds PAG. If the ratio in all rows of Column $\mathrm{C}$ are less than 1.0, then the sample is acceptable. Mark the box This Sample is OK. Ignore Columns D and E for now.

Step 2 Determine Dominant Radionuclides

1. Complete Worksheet B, "Food Contamination Ingestion Analysis."

2. Transcribe results of the four tests from Column $\mathrm{C}$ of Worksheet $\mathrm{B}$ to Column $\mathrm{C}$ of Worksheet C.

3. In Column D, rank order ratios of both Part 1 and Part 2 results with 1 being the greatest ratio.

4. In Column E, mark all radionuclides with a ratio greater than $1 / 5$ of the most dominant radionuclide ratio (largest ratio) with an $\mathrm{X}$.

5. These are the dominant radionuclides. If any is a minor radionuclide, attach Worksheet $\mathrm{C}$ to Worksheet B as part of the Food Sample Analysis.

\subsection{ATTACHMENTS}

Worksheet A, "Deposition Concentration Ingestion Analysis"

Worksheet B, "Food Contamination Analysis"

Worksheet C, "Minor Radionuclide Analysis" 


\section{Worksheet A}

Deposition Concentration Ingestion Analysis

\begin{tabular}{|l|l|l|}
\hline Sample Control \# & Location: & Analyst: \\
\hline Soil $\square \quad$ Field y Spect. $\square \quad$ Other $\square$ & Latitude: & Date: \\
\hline Description: & Longitude: & Time: \\
\hline
\end{tabular}

If any one contamination test fails, then the sample fails to meet the 1998 FDA PAGs.

\begin{tabular}{|c|c|c|c|c|c|c|c|}
\hline \multicolumn{2}{|l|}{${ }^{90} \mathrm{Sr} \&{ }^{131} \mathrm{I}$ Tests } & Column A & \multicolumn{3}{|c|}{ Column B } & Column C & Column D \\
\hline $\begin{array}{l}\text { Ratio concentration to } \\
\text { corresponding DIL. }\end{array}$ & Nuclide & $\begin{array}{l}\text { Deposition } \\
\text { Concentration } \\
\left(\text { unit }^{\dagger} / \mathrm{m}^{2}\right)\end{array}$ & $\begin{array}{c}\mathrm{DIL}^{\ddagger} \\
\left(\mathrm{Bq} / \mathrm{m}^{2}\right)\end{array}$ & $\begin{array}{c}\mathrm{DIL}^{\ddagger} \\
\left(\mathrm{pCi} / \mathrm{m}^{2}\right)\end{array}$ & $\begin{array}{c}\mathrm{DIL}^{\ddagger} \\
\left(\mu \mathrm{Ci} / \mathrm{m}^{2}\right)\end{array}$ & $\begin{array}{c}\text { A } \div \text { B } \\
\text { Match units } \\
\text { of } A \text { with } B\end{array}$ & $\begin{array}{l}\text { Mark with } \mathbf{X} \text {, } \\
\text { if Column } \mathrm{C} \\
\text { greater than } 1.0\end{array}$ \\
\hline Fail, if ratio $>1.0$ & ${ }^{90} \mathrm{Sr}$ & & 1,600 & 43,000 & $4.3 \times 10^{-2}$ & & \\
\hline † $\mathrm{Bq} / \mathrm{m}^{2}, \mathrm{pCi} / \mathrm{m}^{2}$ or $\mu \mathrm{Ci} / \mathrm{m}^{2}$ & ${ }^{131} \mid$ & & 340 & 9,200 & $9.2 \times 10^{-3}$ & & \\
\hline
\end{tabular}

${ }^{134}$ Cs \& ${ }^{137}$ Cs Test

Ratio sum of both concentrations to corresponding DIL.

Fail, if ratio $>1.0$

$+\mathrm{Bq} / \mathrm{m}^{2}, \mathrm{pCi} / \mathrm{m}^{2}$ or $\mu \mathrm{Ci} / \mathrm{m}^{2}$

\begin{tabular}{|c|c|c|c|c|c|c|}
\hline & Column A & \multicolumn{3}{|c|}{ Column B } & Column C & Column D \\
\hline Nuclide & $\begin{array}{l}\text { Deposition } \\
\text { Concentration } \\
\left(\text { unit }^{\dagger} / \mathrm{m}^{2}\right)\end{array}$ & $\begin{array}{c}\mathrm{DIL}^{\ddagger} \\
\left(\mathrm{Bq} / \mathrm{m}^{2}\right)\end{array}$ & $\begin{array}{c}\mathrm{DIL}^{\ddagger} \\
\left(\mathrm{pCi} / \mathrm{m}^{2}\right)\end{array}$ & $\begin{array}{c}\mathrm{DIL}^{\ddagger} \\
\left(\mu \mathrm{Ci} / \mathrm{m}^{2}\right)\end{array}$ & $\begin{array}{c}\sum \mathbf{A} \div \mathbf{B} \\
\text { Match units } \\
\text { of } A \text { with } B\end{array}$ & $\begin{array}{l}\text { Mark with } \mathbf{X}, \\
\text { if Column } \mathrm{C} \\
\text { greater than } 1.0\end{array}$ \\
\hline${ }^{134} \mathrm{Cs}$ & & & & & & \\
\hline${ }^{137} \mathrm{Cs}$ & & & & & & \\
\hline Sum $\sum A$ & & 12,000 & 320,000 & 0.32 & & \\
\hline
\end{tabular}

${ }^{238,}{ }^{239} \mathrm{Pu} \&{ }^{241} \mathrm{Am}$ Test

Ratio sum of all 3 concentrations to corresponding DIL.

Fail, if ratio $>1.0$

† $\mathrm{Bq} / \mathrm{m}^{2}, \mathrm{pCi} / \mathrm{m}^{2}$ or $\mu \mathrm{Ci} / \mathrm{m}^{2}$

\begin{tabular}{|c|c|c|c|c|c|c|}
\hline & Column A & \multicolumn{3}{|c|}{ Column B } & Column C & Column D \\
\hline Nuclide & $\begin{array}{l}\text { Deposition } \\
\text { Concentration } \\
\left(\text { unit }^{\dagger} / \mathrm{m}^{2}\right)\end{array}$ & $\begin{array}{c}\mathrm{DIL}^{\ddagger} \\
\left(\mathrm{Bq} / \mathrm{m}^{2}\right)\end{array}$ & $\begin{array}{c}\mathrm{DIL}^{\ddagger} \\
\left(\mathrm{pCi} / \mathrm{m}^{2}\right)\end{array}$ & $\begin{array}{c}\mathrm{DIL}^{\ddagger} \\
\left(\mu \mathrm{Ci} / \mathrm{m}^{2}\right)\end{array}$ & $\begin{array}{c}\sum \mathbf{A} \div \mathbf{B} \\
\text { Match units of } \\
\text { A with B }\end{array}$ & $\begin{array}{l}\text { Mark with } \mathbf{X} \\
\text { if Column } \mathrm{C} \\
\text { greater than } 1.0\end{array}$ \\
\hline${ }^{238} \mathrm{Pu}$ & & & & & & \\
\hline${ }^{239} \mathrm{Pu}$ & & & & & & \\
\hline${ }^{241} \mathrm{Am}$ & & & & & & \\
\hline Sum $\sum A$ & & 20 & 540 & $5.4 \times 10^{-4}$ & & \\
\hline
\end{tabular}

\section{${ }^{103}$ Ru \& ${ }^{106}$ Ru Test}

Ratio concentrations to corresponding DILs, then sum.

Fail, if ratio $>1.0$

† $\mathrm{Bq} / \mathrm{m}^{2}, \mathrm{pCi} / \mathrm{m}^{2}$ or $\mu \mathrm{Ci} / \mathrm{m}^{2}$

\begin{tabular}{|c|c|c|c|c|c|c|}
\hline & Column A & \multicolumn{3}{|c|}{ Column B } & Column C & Column D \\
\hline Nuclide & $\begin{array}{l}\text { Deposition } \\
\text { Concentration } \\
\left(\text { unit }^{\dagger} / \mathrm{m}^{2}\right)\end{array}$ & $\begin{array}{c}\mathrm{DIL}^{\ddagger} \\
\left(\mathrm{Bq} / \mathrm{m}^{2}\right)\end{array}$ & $\begin{array}{c}\mathrm{DIL}^{\ddagger} \\
\left(\mathrm{pCi} / \mathrm{m}^{2}\right)\end{array}$ & $\begin{array}{c}\mathrm{DIL}^{\ddagger} \\
\left(\mu \mathrm{Ci} / \mathrm{m}^{2}\right)\end{array}$ & $\begin{array}{c}\text { A } \div \text { B } \\
\text { Match units of } \\
\text { A with B }\end{array}$ & $\begin{array}{c}\text { Mark with } \mathbf{X}, \\
\text { if Column } \mathrm{C} \\
\text { greater than } 1.0\end{array}$ \\
\hline${ }^{103} \mathrm{Ru}$ & & 68,000 & $1.8 \times 10^{6}$ & 1.8 & & \\
\hline${ }^{106} \mathrm{Ru}$ & & 4,500 & 120,000 & 0.12 & & \\
\hline & & & & Sum $\sum C$ & & \\
\hline
\end{tabular}

\section{This Sample}

\section{is $O K$}

\section{Exceeds PAG}

¥ Food concentration DILs converted to deposition DILs assuming $2 \mathrm{~kg} / \mathrm{m}^{2}$ productivity and retention=0.2, except iodine $=1.0$ 


\section{Worksheet B}

Food Contamination Analysis

\begin{tabular}{|l|l|l|}
\hline Sample Control \# & Location: & Analyst: \\
\hline Food $\square \quad$ Milk $\square \quad$ Feed $\square$ Other $\square$ & Latitude: & Date: \\
\hline Description: & Longitude: & Time: \\
\hline
\end{tabular}

If any one contamination test fails, then the sample fails to meet the 1998 FDA PAGs.

${ }^{90} \mathrm{Sr} \&{ }^{131}$ I Tests

Ratio concentration to corresponding DIL.

Fail, if ratio $>1.0$

† Bq/kg, pCi/kg or $\mu \mathrm{Ci} / \mathrm{kg}$

${ }^{134}$ Cs \& ${ }^{137}$ Cs Test

Ratio sum of both concentrations to corresponding DIL.

Fail, if ratio $>1.0$

† Bq/kg, pCi/kg or $\mu \mathrm{Ci} / \mathrm{kg}$

\begin{tabular}{|c|c|c|c|c|c|c|}
\hline & Column A & \multicolumn{3}{|c|}{ Column B } & Column C & Column D \\
\hline Nuclide & $\begin{array}{c}\text { Food } \\
\text { Concentration } \\
\text { (unit } / / \mathrm{kg} \text { ) }\end{array}$ & $\begin{array}{c}\text { DIL } \\
(\mathrm{Bq} / \mathrm{kg})\end{array}$ & $\begin{array}{c}\text { DIL } \\
(p C i / k g)\end{array}$ & $\begin{array}{c}\text { DIL } \\
(\mu \mathrm{Ci} / \mathrm{kg})\end{array}$ & $\begin{array}{c}\sum \mathbf{A} \div \mathbf{B} \\
\text { Match units } \\
\text { of } A \text { with } B\end{array}$ & $\begin{array}{l}\text { Mark with } \mathbf{X}, \\
\text { if Column } \mathrm{C} \\
\text { greater than } 1.0\end{array}$ \\
\hline${ }^{134} \mathrm{Cs}$ & & & & & & \\
\hline${ }^{137} \mathrm{Cs}$ & & & & & & \\
\hline Sum $\sum A$ & & 1,200 & 32,000 & $3.2 \times 10$ & & \\
\hline
\end{tabular}

${ }^{238,}{ }^{239} \mathrm{Pu} \&{ }^{241} \mathrm{Am}$ Test

Ratio sum of all 3 concentrations to corresponding DIL.

Fail, if ratio $>1.0$

† Bq/kg, pCi/kg or $\mu \mathrm{Ci} / \mathrm{kg}$

\begin{tabular}{|c|c|c|c|c|c|c|}
\cline { 2 - 7 } \multicolumn{1}{c|}{} & Column A & \multicolumn{3}{c|}{ Column B } & Column C & Column D \\
\hline Nuclide & $\begin{array}{c}\text { Food } \\
\text { Concentration } \\
(\text { unit } / \mathrm{kg})\end{array}$ & $\begin{array}{c}\text { DIL } \\
(\mathrm{Bq} / \mathrm{kg})\end{array}$ & $\begin{array}{c}\mathrm{DIL} \\
(\mathrm{pCi} / \mathrm{kg})\end{array}$ & $\begin{array}{c}\text { DIL } \\
(\mu \mathrm{Ci} / \mathrm{kg})\end{array}$ & $\begin{array}{c}\text { A } \div \text { B } \\
\text { Match units } \\
\text { of A with B }\end{array}$ & $\begin{array}{c}\text { Mark with X, } \\
\text { if Column C } \\
\text { greater than } 1.0\end{array}$ \\
\hline${ }^{90} \mathrm{Sr}$ & & 160 & 4,300 & $4.3 \times 10^{-3}$ & & \\
\hline${ }^{131} \mathrm{I}$ & & 170 & 4,600 & $4.6 \times 10^{-3}$ & & \\
\hline
\end{tabular}

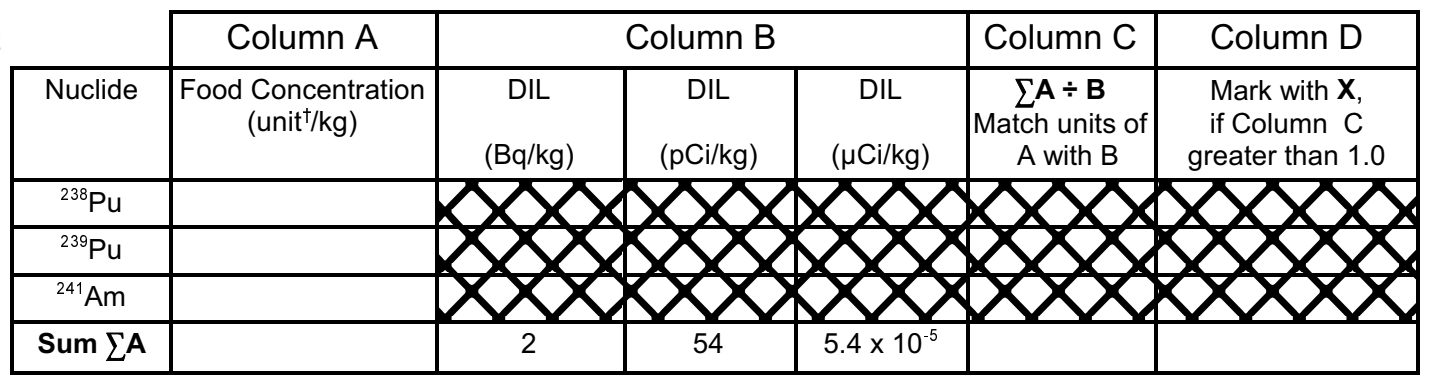

${ }^{103}$ Ru \& ${ }^{106}$ Ru Test

Ratio concentrations to corresponding DILs, then sum.

Fail, if ratio $>1.0$

† $\mathrm{Bq} / \mathrm{kg}, \mathrm{pCi} / \mathrm{kg}$ or $\mu \mathrm{Ci} / \mathrm{kg}$

\begin{tabular}{|c|c|c|c|c|c|c|}
\hline & Column A & \multicolumn{3}{|c|}{ Column B } & Column C & Column D \\
\hline Nuclide & $\begin{array}{l}\text { Food Concentration } \\
\text { (unit }{ }^{\dagger} / \mathrm{kg} \text { ) }\end{array}$ & $\begin{array}{c}\text { DIL } \\
(\mathrm{Bq} / \mathrm{kg})\end{array}$ & $\begin{array}{c}\text { DIL } \\
(p C i / k g)\end{array}$ & $\begin{array}{c}\text { DIL } \\
(\mu \mathrm{Ci} / \mathrm{kg})\end{array}$ & $\begin{array}{c}\mathbf{A} \div \mathbf{B} \\
\text { Match units of } \\
\text { A with B }\end{array}$ & $\begin{array}{l}\text { Mark with X, } \\
\text { if Column C } \\
\text { greater than } 1.0\end{array}$ \\
\hline${ }^{103} \mathrm{Ru}$ & & 6,800 & 180,000 & $1.8 \times 10^{-1}$ & & \\
\hline${ }^{106} \mathrm{Ru}$ & & 450 & 12,000 & $1.2 \times 10^{-2}$ & & \\
\hline & & & & Sum $\sum C$ & & \\
\hline
\end{tabular}

is $O K$ 


\section{Worksheet C}

Minor Radionuclide Analysis

\begin{tabular}{|l|l|l|}
\hline Sample Control \# & Location: & Analyst: \\
\hline Food $\square \quad$ Milk $\square \quad$ Feed $\square$ Other $\square$ & Latitude: & Date: \\
\hline Description: & Longitude: & Time: \\
\hline
\end{tabular}

If any one contamination test fails, then the sample fails to meet the 1998 FDA PAGs.

\section{Part 1 Minor Radionuclides}

Ratio concentration to corresponding DIL.

Fail

if ratio $>1.0$ in any row

† $\mathrm{Bq} / \mathrm{kg}, \mathrm{pCi} / \mathrm{kg}$ or $\mu \mathrm{Ci} / \mathrm{kg}$

\begin{tabular}{|c|c|c|c|c|c|c|c|}
\hline & $\begin{array}{c}\text { Column } \\
\mathrm{A}\end{array}$ & & $\underset{\mathrm{B}}{\text { Column }}$ & & $\underset{\mathrm{C}}{\text { Column }}$ & $\begin{array}{c}\text { Column } \\
\text { D }\end{array}$ & $\begin{array}{c}\text { Column } \\
\mathrm{E}\end{array}$ \\
\hline Nuclide & $\begin{array}{c}\text { Food } \\
\text { Concentration } \\
\left.\text { (unit }{ }^{\dagger} / \mathrm{kg}\right)\end{array}$ & $\begin{array}{c}\text { DIL } \\
(\mathrm{Bq} / \mathrm{kg})\end{array}$ & $\begin{array}{c}\text { DIL } \\
(p C i / k g)\end{array}$ & $\begin{array}{c}\text { DIL } \\
(\mu \mathrm{Ci} / \mathrm{kg})\end{array}$ & $\begin{array}{c}\mathbf{A} \div \mathbf{B} \\
\text { Match units of } \\
\text { A with } B\end{array}$ & $\begin{array}{l}\text { Rank } \\
\text { Order }\end{array}$ & $\begin{array}{c}\text { Mark, if } \\
\text { domi- } \\
\text { nant }\end{array}$ \\
\hline${ }^{89} \mathrm{Sr}$ & & 1,400 & 38,000 & $3.8 e-02$ & & & \\
\hline${ }^{91} \mathrm{Y}$ & & 1,200 & 32,000 & $3.2 \mathrm{e}-02$ & & & \\
\hline${ }^{95} \mathrm{Zr}$ & & 4,000 & 110,000 & $1.1 \mathrm{e}-01$ & & & \\
\hline${ }^{95} \mathrm{Nb}$ & & 12,000 & 320,000 & $3.2 \mathrm{e}-01$ & & & \\
\hline${ }^{132} \mathrm{Te}$ & & 4,400 & 120,000 & $1.2 \mathrm{e}-01$ & & & \\
\hline${ }^{129} I$ & & 56 & 1,500 & $1.5 \mathrm{e}-03$ & & & \\
\hline 133 & & 7,000 & 190,000 & $1.9 \mathrm{e}-01$ & & & \\
\hline${ }^{140} \mathrm{Ba}$ & & 6,900 & 190,000 & $1.9 \mathrm{e}-01$ & & & \\
\hline${ }^{141} \mathrm{Ce}$ & & 7,200 & 200,000 & $2.0 \mathrm{e}-01$ & & & \\
\hline${ }^{144} \mathrm{Ce}$ & & 500 & 14,000 & $1.4 \mathrm{e}-02$ & & & \\
\hline${ }^{237} \mathrm{~Np}$ & & 4 & 110 & $1.1 \mathrm{e}-04$ & & & \\
\hline${ }^{239} \mathrm{~Np}$ & & 28,000 & 760,000 & $7.6 e-01$ & & & \\
\hline${ }^{241} \mathrm{Pu}$ & & 120 & 3,200 & $3.2 \mathrm{e}-03$ & & & \\
\hline${ }^{242} \mathrm{Cm}$ & & 19 & 510 & $5.1 \mathrm{e}-04$ & & & \\
\hline${ }^{244} \mathrm{Cm}$ & & 2 & 54 & $5.4 \mathrm{e}-05$ & & & \\
\hline
\end{tabular}

If any one test fails,then the sample exceeds PAG.

\section{\begin{tabular}{l|l|l} 
This Sample & is OK $\square$ & Exceeds PAG \\
\hline
\end{tabular}}

\begin{tabular}{|c|c|c|c|c|c|}
\hline \multirow[t]{6}{*}{$\begin{array}{l}\text { Part } 2 \\
\text { Dominant } \\
\text { Radionuclides }\end{array}$} & $\begin{array}{l}\text { Results from Worksheet B } \\
\text { Enter ratio from Column C of } \\
\text { Worksheet B. }\end{array}$ & Nuclide & $\begin{array}{c}\text { Column C } \\
\text { Ratio from } \\
\text { Worksheet B }\end{array}$ & $\begin{array}{c}\text { Column D } \\
\text { Rank } \\
\text { Order }\end{array}$ & $\begin{array}{c}\text { Column E } \\
\text { Mark, if } \\
\text { dominant }\end{array}$ \\
\hline & Rank Order 1 to $n$ with above. & ${ }^{90} \mathrm{Sr}$ & & & \\
\hline & Greatest ratio is most dominant. & ${ }^{131}$ I & & & \\
\hline & Mark Column E in both Part 1 & ${ }^{134} \mathrm{Cs}+{ }^{137} \mathrm{Cs}$ & & & \\
\hline & and Part 2 with $\mathbf{X}$, if ratio $>1 / 5$ & ${ }^{238,239} \mathrm{Pu} \mathrm{\&}{ }^{241} \mathrm{Am}$ & & & \\
\hline & of most dominant radionuclide. & ${ }^{103} \mathrm{Ru} \&{ }^{106} \mathrm{Ru}$ & & & \\
\hline
\end{tabular}


FRMAC ASSESSMENT WORKING GROUP MEMBERS

Baskett, R

Bores, $\mathrm{R}$

Buhl, T

Clark, HW

Dempsey, GD

Gee, R

Gray, K

Hoffman, L

Johnson, $\mathrm{N}$

Krutchten, D

Maguire, SA

McKenna, TJ

Myers, D

Patterson, $\mathrm{J}$

Pohl, K

Stang, $\mathrm{P}$
LLNL/ARAC

NRC/R 1

LANL

BN

$\mathrm{EPA} / \mathrm{LV}$

ORNL

CDC

LANL (Document distributed by e-mail)

LLNL

$\mathrm{NRC} / \mathrm{HQ}$

$\mathrm{NRC} / \mathrm{HQ}$

LLNL

USDA

EPA/NAREL

$\mathrm{DOE} / \mathrm{HQ}$

OTHER RELATED INTERESTS

Bowman, D

Keller, J

O'Laughlin, C

Riland, C

Thompson, $\mathrm{R}$

Thompson, D

Tighe, $\mathrm{R}$

RESOURCE CENTERS

OSTI

DOE Public Reading Facility

TIRC
$\mathrm{BN}$

INEEL

DOE/NV

BN

DOE/NV

FDA

BN

FRMAC ASSESSMENT MANUAL ADDENDUM DOE/NV/11718--061-ADD

DECEMBER 1999 